\title{
Risk management of NATURA 2000 sites in Czech military training areas
}

\author{
F. Bozek ${ }^{1}$, A. Komar $^{1}$, J. Dvorak ${ }^{2}$, A. Bozek ${ }^{3} \&$ L. Jesonkova ${ }^{1}$ \\ ${ }^{1}$ University of Defence, Faculty of Economics and Management, Brno, \\ Czech Republic \\ ${ }^{2}$ University of Defence, Language Training Centre, Brno, Czech Republic \\ ${ }^{3}$ University of Technology, Faculty of Mechanical Engineering, \\ Brno, Czech Republic
}

\begin{abstract}
The military training areas have a number of NATURA 2000 sites many of which exist because of particular military activities being carried out in the areas. The aim of implementing risk management is to provide protection to the selected species of plants, animals and natural habitats being the most precious from the European perspective.

Environmental protection during military training in the Armed Forces of the Czech Republic implicitly includes also the risk management and is guaranteed in the following processes. The commander has to elaborate a precise environmental protection regulation as a part of planning process to be followed during a training or operation according to NATO standardization agreements. Documentation is a part of operational planning or a training regulation.

It accepts the character of habitats, way of training and includes preventive measures. Environmental training of personnel, delegation of responsibilities and resources use are aimed at providing environmental security.

The semi-quantitative case study has been focused on threat identification, as well as on the determination and assessment of risk acceptability in the examined NATURA 2000 site inside the military training area. A number of undesirable, but tolerable risks have been found, most of them belong to the category of controllable risks. It is possible to implement adequate countermeasures, mainly of organizational nature with minimal risk mitigation costs. It is worth mentioning that a number of risks which have relatively high values ensue solely from the planning activities, lack of discipline and knowledge of NATURA 2000
\end{abstract}


sites. No cooperation with state administration bodies, trainees' ignorance of protected species and habitats, inadequately set priorities for maintained areas belong to above mentioned category. Reduction of such risks should be given priority. Unacceptable risk is specific and results from the lack of financial resources, for the maintenance management.

Keywords: case study, habitats, maintenance military training areas, NATURA 2000 sites, risk assessment, risk identification semi-quantitative method, training plan.

\section{Introduction}

Nature and landscape in the Czech Republic is protected in compliance with general rules and commitments resulting from the national Code of Law, its legal regulations $[1,2]$ and the Directives of the EU [3, 4]. The principles of environmental protection in the military sector are defined in the basic regulation of the Czech Armed Forces [5]. Environmental protection during NATO led operations and contractual training of troops is supported according to MC 469 [6] and STANAG 7141 EP [7]. All military activities with a possible impact on the environment have to be carried out in compliance with the legal system of the Czech Republic, which mostly transposes the EU legislation. A similar approach can be seen in the last period in NATO standard prepared for the sustainability of Military Training Areas (MTAs) [8].

The implementation of risk management is a significant proactive tool contributing to the effective allocation of financial, material and personal resources in the environmental protection during military training in the military training areas.

\section{The theoretical part}

Environmental protection in the Armed Forces of the Czech Republic implicitly includes also the risk management and is guaranteed in the following process:

a) The commander has to elaborate a precise environmental protection regulation as a part of planning process to be followed during a training or operation;

b) Documentation is a part of operational planning or a training regulation. It accepts the character of training and area and includes measures to be taken in case of emergency;

c) Environmental training of personnel, delegation of responsibilities and resources for providing security to the environment, personnel and utilized facilities.

\subsection{Protection of nature and landscape in training areas}

Commanders of MTAs in military domains elaborate statutes in which there are the principles of environmental protection. They are based on the environmental law and include the general responsibilities of the chief of MTA operational 
centre, equipment operators and the commanders of training units in the area of MTA environmental protection. The basic responsibilities in the areas of waste management and the protection of air, soil and water are stated as well. The operational centre compiles the operation rules for the MTA environmental protection in which the principles of environmental protection are developed in compliance with valid legislation. Before training a commander and training troops are informed about territorial plans of military domains, operational rules and the system of environmental protection during the deployment in MTA. The equipment operators, their superiors, unit commanders and supervisory bodies are responsible for obeying operational and environmental protection principles.

An allied exercise is preceded by a thorough planning. The legal preparation ensues from the Status of Forces Agreement (SOFA). Agreements during the preparation of training are concluded in co-operation with the Logistic Section and its MoD Environmental Office. Stricter environmental protection legal amendment has to be abidden in the proposal of environmental plan.

The attention of environmental committee and organizational and logistic preparation is aimed at such activities, which have impacts on environment, mainly accommodation, catering, transport, water supply, waste water treatment, parking and washing of vehicles, waste management, petroleum, oil and lubrications supply, and the equipment of emergency and environmental teams.

\subsection{Specificities of military activities under NATURA 2000 conditions}

The environmental protection during training is carried out in co-operation with civil authorities and state administration on the territories, which are not under the Ministry of Defence management. Protection is carried out in compliance with valid legislation and international agreements [9].

NATURA sites must not be used for contract training. Natural habitats were formed under the conditions of long-term sustainable utilization and such conditions are parts of given site military management. Non-traditional utilization of sites would be in contradiction with required management. Some of them have recently been developed within an important short-term NATO project [10]. The following standards concern environmental protection standards and norms [11], best environmental protection practices [12], an Environmental Management System (EMS) in NATO operations [13] and environmental files for military compounds [14].

The European Union FORces environmental bodies agreed to implement a broad concept of environmental protection within the European Security and Defence Policy. It includes four implemented documents dealing with environmental policy, status assessment guidelines, EMS and environmental bodies [15-18]. A document on reporting environmental accidents is being prepared as well.

The shortcoming of all the adopted and prepared materials is that the protection of nature and landscape is managed indirectly, through e.g. waste management, protection of soil, water, etc. [19]. Moreover the documents do not include terms such as NATURA 2000 and the corresponding terminology such 
as Special Protected Areas, Birds Areas, European Significant Habitats, Natural Habitats, European Significant Species, National List of Habitats, etc.

\section{Applied methods}

The semi-quantitative risk assessment of environmental damage in the NATURA 2000 habitat caused by military training was based on the general risk management procedure, which is shown in the Figure 1 [20].

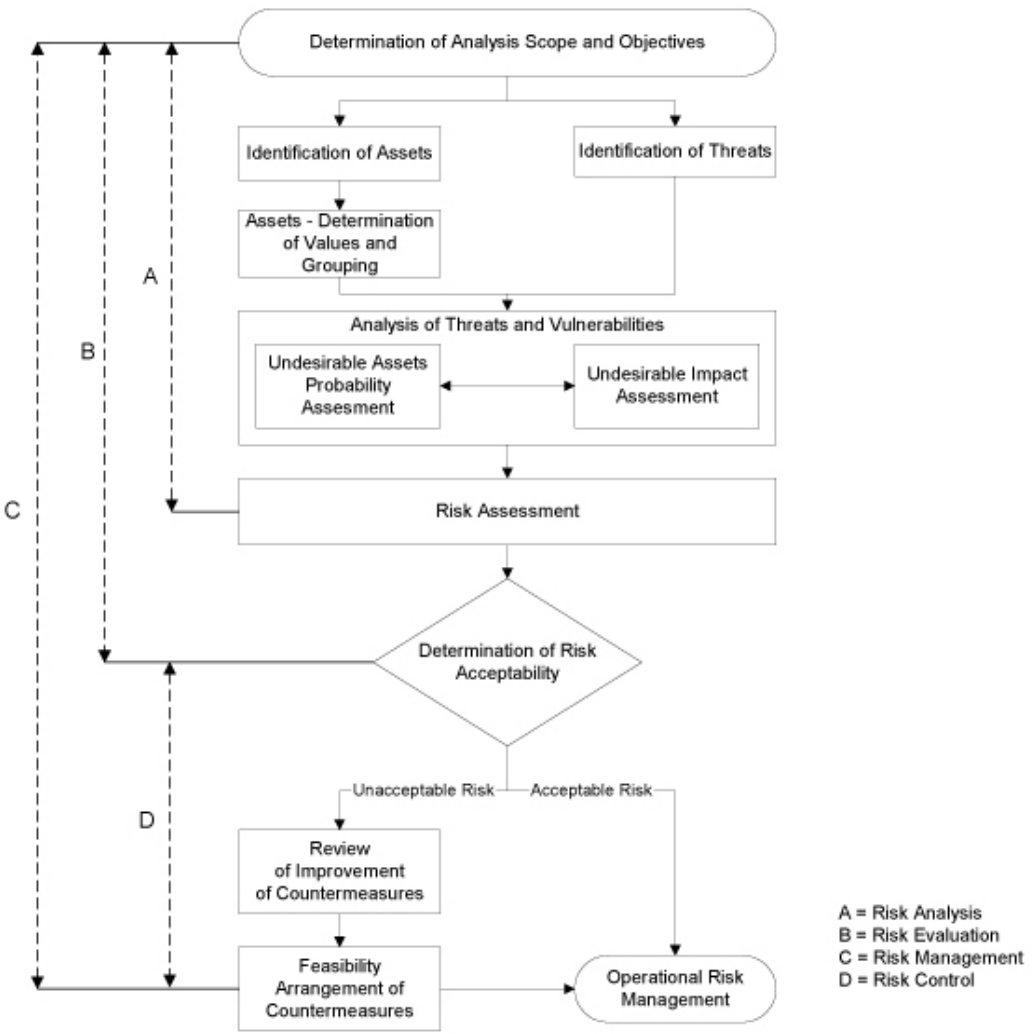

Figure 1: General phases of risk management and their sequence.

The Check List Analysis method has been used for compiling the list of threats for the NATURA 2000 habitat in the selected training area [21, 22]. The method included environmental maps, questionnaires, on-site discussions and historical data. Brainstorming has been applied for determining the index point values representing the occurrence probability of identified threats and their impacts. The assessment has been carried out in the group of 12 people, three 
experts in the protection of nature and landscape, the chief environmentalist of the Army of the Czech Republic, a commander and a specialist in environmental protection of the assessed MTA, five regular training participants, and one laic. The same method has been used for assessing the acceptability of risk index point values acquired through calculation according to the equation (1):

$$
I R_{j}(\tau)=I P_{j}(\tau) \times I N_{j}(\tau)
$$

where $I R_{j}(\tau)$ represents the risk index point value, $I P_{j}(\tau)$ is the index point value of threat occurrence probability, and $I N_{j}(\tau)$ is the index point value of impact of a $j$-threat in time $\tau$.

\section{Outcomes and discussion}

There are number of NATURA 2000 sites in the military training areas of the Czech Republic. A number of these sites have been established exclusively as a result of particular military activities. In order to maintain or increase their current quality it is advisable to implement pro-active preventive tools in the phase of preparation and realization of training as well as in the management process of their maintenance. We believe that risk management is particularly suitable tool in relation to NATURA 2000 sites.

Environmentally unfriendly training or maintenance of the mentioned sites may damage or destroy individual elements of sites and thus cause environmental detriment to the environment. The goal of implementing risk management is to protect the selected habitats and flora and fauna species that are the most precious from the European viewpoint, i.e. the most endangered, rare, or endemic. A semi-quantitative analysis is commonly sufficient for estimating the risks resulting from real threats. The presented case study is limited to the selected NATURA 2000 site located in the Czech MTA and can be used as an example for risk assessment supporting the protection of other NATURA 2000 sites.

The Check List Analysis Method has been chosen for identifying threats. The information acquired from the study of documentation of selected sites has been used in questionnaires and interviews with the stakeholders holding different posts in the process of training of troops and the maintenance of MTA. The criteria in the selection of stakeholders were their specializations as well as the "ability to communicate". The acquired results have been evaluated with help of traditional brainstorming and served for building the register of threats, which has been divided into three categories, namely the threats arising from the preparation of training, training, and maintenance management of NATURA 2000 sites.

The assessment of probability index point value $I P_{j}$ of the activation of every identified $j$-threat $T_{j}$, where $j \in\langle 1 ; 25\rangle \wedge j \in \mathrm{N}^{*}$ and $\mathrm{N}^{*}$ represents the symbol for the set of natural numbers, was carried out with the use of traditional brainstorming on the basis of results which were obtained through the Check List Analysis method and on-site interview. The threat activation probability was 
assessed in compliance with the data presented in the Table 1 in the range of values $P_{j}=m$, where $m \in(1 ; 5\rangle \wedge m \in \mathrm{Re}^{+}$and $\mathrm{Re}^{+}$means the symbol for the set of all real positive numbers.

Table 1: Verbal description of index point values in dependence on the threat source activation probability.

\begin{tabular}{|c|l|}
\hline Interval of index point value of probability IP & \multicolumn{1}{|c|}{$\begin{array}{l}\text { Verbal description of threat source activation } \\
\text { probability }\end{array}$} \\
\hline$(0 ; 1\rangle$ & $\begin{array}{l}\text { Negligible. The emergence of undesirable event } \\
\text { is almost excluded. }\end{array}$ \\
\hline$(1 ; 2\rangle$ & $\begin{array}{l}\text { Low. The activation of threat source is unlikely, } \\
\text { but possible. }\end{array}$ \\
\hline$(2 ; 3\rangle$ & $\begin{array}{l}\text { Middle. The activation of threat source in the } \\
\text { specified time can happen. }\end{array}$ \\
\hline$(3 ; 4\rangle$ & $\begin{array}{l}\text { High. The occurrence of threat in the specified } \\
\text { time is common. }\end{array}$ \\
\hline$(4 ; 5\rangle$ & $\begin{array}{l}\text { Very high. The threat is manifested frequently } \\
\text { or continuously. }\end{array}$ \\
\hline
\end{tabular}

Table 2: $\quad$ Verbal description of index point values in dependence on the level of impact.

\begin{tabular}{|c|l|}
\hline $\begin{array}{c}\text { Interval of index point value of } \\
\text { impact } I N\end{array}$ & Verbal description of impact level \\
\hline$(0 ; 1\rangle$ & $\begin{array}{l}\text { Negligible. The evaluated group of assets is } \\
\text { sufficiently resistant to threat and at the same } \\
\text { time almost insignificant for the } \\
\text { NATURA 2000 site. }\end{array}$ \\
\hline$(1 ; 2\rangle$ & $\begin{array}{l}\text { Marginal. Firstly, the evaluated group of } \\
\text { assets is relatively susceptible to the effects of } \\
\text { hazard, but it has a low value. Secondly, the } \\
\text { group of assets is sufficiently resistant to } \\
\text { hazard, but it has higher value for the } \\
\text { NATURA 2000 site. }\end{array}$ \\
\hline$(2 ; 3\rangle$ & $\begin{array}{l}\text { Critical. The sensitivity of the asset is } \\
\text { relatively high and its importance for further } \\
\text { development of the NATURA 2000 site is } \\
\text { relatively large. }\end{array}$ \\
\hline \multirow{3}{*}{$3 ; 4\rangle$} & $\begin{array}{l}\text { Catastrophic. The evaluated group of assets is } \\
\text { highly sensitive to the action of hazard and its } \\
\text { importance for the NATURA 2000 site is vital } \\
\text { or irreplaceable. The group of assets is either } \\
\text { difficult to be renewed or is completely } \\
\text { non-renewable. }\end{array}$ \\
\hline
\end{tabular}


It was even more difficult to assess the level of environmental detriment or damage as an index point value of impact $I N_{j}$ for the activation of $j$-threat. The estimate has been realized similarly to the probability assessment of the index point value $I P_{j}$ in compliance with the data stated in the Table 2 in the range of values $I N_{j}=q$, where $q \in(0 ; 4\rangle \wedge q \in \mathrm{Re}^{+}$, again with the expert assessment and reconciliation of available data done by the brainstorming group members. The sensibility and criticality of the protected elements of NATURA 2000 sites were mainly considered. The elements of NATURA 2000 site were classified into the following groups (groupings of assets):

a) bird areas;

b) natural habitats;

c) protected species of flora;

d) protected species of fauna.

with special attention paid to the impacts on flora and fauna.

The acquired index point values $I P_{j}$ and $I N_{j}$ were used for the risk assessment in the form of indexes $I R_{j}$ that were calculated according to the formula (1) while disregarding time dependence $I P_{j}(t)$ and $I N_{j}(\mathrm{t})$ and in compliance with the matrix of risk assessment in points presented in Table No 3. Point assessment from the Table No 4 was used for the description of risks. The outcomes are comprehensively presented in Table No 5.

Table 3: $\quad$ Matrix of risk index point values $I R$.

\begin{tabular}{|l|c|c|c|c|}
\hline Probability/impact & $(0 ; 1\rangle$ negligible & $(1 ; 2\rangle$ marginal & $(2 ; 3\rangle$ critical & $(3 ; 4\rangle$ catastrophic \\
\hline$(0 ; 1\rangle$ negligible & $(0 ; 1\rangle$ & $(0 ; 1\rangle$ & $(0 ; 3\rangle$ & $(0 ; 4\rangle$ \\
\hline$(1 ; 2\rangle$ low & $(0 ; 2\rangle$ & $(1 ; 4\rangle$ & $(2 ; 6\rangle$ & $(3 ; 8\rangle$ \\
\hline$(2 ; 3\rangle$ medium & $(0 ; 3\rangle$ & $(2 ; 6\rangle$ & $(4 ; 9\rangle$ & $(6 ; 12\rangle$ \\
\hline$(3 ; 4\rangle$ high & $(0 ; 1\rangle$ & $(3 ; 8\rangle$ & $(6 ; 12\rangle$ & $(9 ; 16\rangle$ \\
\hline$(4 ; 5\rangle$ very high & $(0 ; 5\rangle$ & $(4 ; 10\rangle$ & $(8 ; 15\rangle$ & $(12 ; 20\rangle$ \\
\hline
\end{tabular}

Table 4: Characteristics of risks according to the intervals of their index point values $I R$.

\begin{tabular}{|c|l|}
\hline $\begin{array}{c}\text { Interval of index point } \\
\text { value of risk } I R\end{array}$ & \multicolumn{1}{c|}{ Risk characteristics } \\
\hline$(0 ; 3\rangle$ & Negligible. Countermeasures need not be implemented. \\
\hline$(3 ; 7\rangle$ & $\begin{array}{l}\text { Acceptable. Countermeasures may be implemented with the agreement } \\
\text { of the MTA commander. }\end{array}$ \\
\hline$(7 ; 11\rangle$ & Tolerable. It is necessary to take countermeasures by a certain deadline. \\
\hline$(11 ; 20\rangle$ & $\begin{array}{l}\text { Unacceptable. It is necessary to stop the activity or immediately } \\
\text { implement countermeasures aimed at its minimization. }\end{array}$ \\
\hline
\end{tabular}


Table 5: Threat identification and risk assessment for observed NATURA 2000 site.

\begin{tabular}{|c|c|c|c|c|c|}
\hline Phase & $T_{j}$ & Description of threat $T_{j}$ & $I P_{j}$ & $I N_{j}$ & $I R_{j}$ \\
\hline \multirow{8}{*}{$\begin{array}{l}\text { Preparation of } \\
\text { training }\end{array}$} & 1 & $\begin{array}{l}\text { No instructions provided to the training } \\
\text { participants }\end{array}$ & 1.6 & 3.1 & 4.96 \\
\hline & 2 & $\begin{array}{l}\text { No co-operation with state administration } \\
\text { bodies }\end{array}$ & 3.9 & 2.4 & 9.36 \\
\hline & 3 & $\begin{array}{l}\text { No co-operation with the MTA } \\
\text { environmentalist }\end{array}$ & 0.6 & 3.3 & 1.98 \\
\hline & 4 & $\begin{array}{l}\text { No training provided to the operational } \\
\text { centre of military facility }\end{array}$ & 1.8 & 3.3 & 5.94 \\
\hline & 5 & $\begin{array}{l}\text { Poorly developed environmental plan of } \\
\text { training }\end{array}$ & 2.7 & 3.5 & 8.91 \\
\hline & 6 & Neglected NATURA 2000 site & 0.9 & 3.8 & 3.42 \\
\hline & 7 & Changes of weather conditions & 3.1 & 2.9 & 8.99 \\
\hline & & Sum & & & 43.56 \\
\hline \multirow{12}{*}{ Training } & 8 & Changes of weather conditions & 2.6 & 2.9 & 7.54 \\
\hline & 9 & Change of training doctrine & 2.4 & 3.6 & 8.64 \\
\hline & 10 & No fulfilling of training doctrine & 1.8 & 2.7 & 4.86 \\
\hline & 11 & Change of MTA use concept & 2.2 & 3.8 & 8.36 \\
\hline & 12 & $\begin{array}{l}\text { Noncompliance with and breach of training } \\
\text { plan }\end{array}$ & 1.2 & 3.3 & 3.96 \\
\hline & 13 & $\begin{array}{l}\text { Trainees' ignorance of protected species } \\
\text { and habitats }\end{array}$ & 4.6 & 2.3 & 10.58 \\
\hline & 14 & Indiscipline of individuals & 3.8 & 2.6 & 9.88 \\
\hline & 15 & Neglected NATURA 2000 site & 1.3 & 3.8 & 4.94 \\
\hline & 16 & No remedy of negative impacts of training & 0.8 & 2.7 & 2.16 \\
\hline & 17 & Serious breakdowns & 1.5 & 3.6 & 5.4 \\
\hline & 18 & No introduction of mitigating measures & 3.0 & 3.0 & 9.0 \\
\hline & & Sum & & & 75.32 \\
\hline \multirow{8}{*}{$\begin{array}{l}\text { Management of } \\
\text { maintenance }\end{array}$} & 19 & $\begin{array}{l}\text { Low budget for the management of } \\
\text { maintenance }\end{array}$ & 4.1 & 3.1 & 12.71 \\
\hline & 20 & Absence of qualified maintenance & 1.2 & 2.4 & 2.88 \\
\hline & 21 & $\begin{array}{l}\text { Unsuitable weather and soil conditions for } \\
\text { maintenance }\end{array}$ & 1.0 & 2.8 & 2.80 \\
\hline & 22 & Phenologically inappropriate maintenance & 1.9 & 3.0 & 5.70 \\
\hline & 23 & Cancellation of contract & 0.9 & 3.4 & 3.06 \\
\hline & 24 & Improper management of maintenance & 2.8 & 2.2 & 6.16 \\
\hline & 25 & $\begin{array}{l}\text { Inadequately set priorities for maintained } \\
\text { areas }\end{array}$ & 2.6 & 3.2 & 8.32 \\
\hline & & Sum & & & 41.63 \\
\hline
\end{tabular}

It is clear from Table No 5 , that tolerable risks in our assessed site are the risks $R_{2}, R_{5}, R_{7}, R_{8}, R_{9}, R_{11}, R_{13}, R_{14}, R_{18}$ and $R_{25}$, out of which the risks $R_{7}, R_{8}, R_{9}$ and $R_{11}$ are either uncontrollable or hardly controllable. Uncontrollable or hardly controllable risks result from the changes of weather conditions and conceptual decisions. In other cases it is possible to implement adequate countermeasures, mostly of organizational character with minimal risk reduction costs. Relatively high levels of index point values of risks $R_{2}, R_{5}, R_{13}, R_{14}, R_{18}$ and $R_{25}$ are worth mentioning as they result solely from the lack of discipline or knowledge of particular stakeholders. The priority should be given to their reduction. 
Unacceptable risk $R_{19}$ is specific and results usually from the lack of financial, but often also from the lack of personal and material resources for the management of maintenance.

It is necessary to mention that the register of threats shown in Table 3 is not limited and may be modified in the course of continual and systematic risk management. It is also necessary to point out that an analogical statement can be made for the assessment of index point values $I P_{j}, I N_{j}$ and thus also for the risk description given by index $I R_{j}$, the values of which range in a broad interval depending on an activity, the character of assessed NATURA 2000 site and number of other factors. Due to the fact that the time dependence has been disregarded it is recommended to carry out the risk analysis and assessment annually.

The case study may therefore be considered to be rather one of possible general procedures used by military units, training commanders, MTA commanders and the authorized regional management to assess the threats to NATURA 2000 sites resulting from not only military but also from civil activities and the management of own maintenance.

\section{Conclusion}

The Declaration of NATURA 2000 became a significant tool of protecting nature in the European Union. It is a new phenomenon in the landscape development in the Czech Republic, especially with regard to MTAs management. Military management welcomes the appeal to more effective environmental protection during military activities. After 10 years of experience risk assessment proved to be a suitable tool for protecting the elements of NATURA 2000 sites, which is accepted in the Department of Defence.

The presented case study of risk assessment may serve as an example of general procedure during military activities and the management of maintenance with regard to NATURA 2000. It has to be mentioned that the threats identified during the required management are variable on local conditions and the nature of military activities. The quantitative value of assessed risk may vary in relation to individual threats. The list of threats is not final and may be supplemented or modified.

\section{Acknowledgement}

The paper has been written as a partial outcome of the research which has been carried out within the framework of the research plan of the Organization Development Project entitled "Environmental Security and Decision Making Processes in the Emergency Management", granted by the Ministry of Defence of the Czech Republic. 


\section{References}

[1] Ministry of Environment (MoE). Act No 114/1992 Coll., on the Protection of Nature and Landscape, as Amended by the Act No 218/2004 Coll., Prague: MoE, 2004.

[2] Government of the Czech Republic. Government Decree No 301/2007 Coll. Amending the Government Decree No 132/2005 Coll., which Determines National List of European Significant Sites. Prague: Government of the Czech Republic, 2007.

[3] The European Economic Community (EEC). Council Directive 79/409/EEC of $2^{\text {nd }}$ April 1979 on the Conservation of Wild Birds. Brussels: EEC, 1979.

[4] The European Economic Community (EEC). Council Directive 92/43/EEC of 21st May 1992 on the Conservation of Natural Habitats and of Wild Fauna and Flora. Brussels: EEC, 1992.

[5] Ministry of Defence (MoD). Zákl-1 Basic Regulation of the Armed Forces of the Czech Republic. Prague: MoD, 1992.

[6] NATO. MC 469 (Final) - NATO Military Principles and Policies for Environmental Protection. Mons, 2003.

[7] NATO Standardization Agency (NSA). STANAG 7141. Joint NATO Doctrine for Environmental Protection during NATO Led Activities. $5^{\text {th }} \mathrm{Ed}$. Brussels: NSA, 2008.

[8] NATO. Best Environmental Protection Practices for Sustainability of Military Training Areas. AJEPP 8 (STANAG XXXX, Draft 1 prepared by expert working team). NATO Standardization Agency (NSA). Ingolstadt, 2012.

[9] Chytry, M., et al. Catalogue of Habitats of the Czech Republic: Interpretive Guide to Europeans Program NATURA 2000 and Emerald. Prague. 2000. ISBN 80-86064-55-7.

[10] NATO/Science for Peace and Security (NATO/SPS). Environmental Aspects of Military Compounds. (Report No. 283), Brussels: NATO/SPS, 2008.

[11] NATO. Environmental Protection Standards and Norms for Military Compound in NATO Operations. AJEPP-1 (STANAG 2581). Brussels: NATO Standardization Agency (NSA). 2010.

[12] NATO. Best Environmental Protection Practices for Military Compound in NATO Operations. AJEPP-2. (STANAG 2580). Brussels: NATO Standardization Agency (NSA). 2010.

[13] NATO. Environmental Management System in NATO Operations. AJEPP3. (STANAG 2538). Brussels: NATO Standardization Agency (NSA). 2011.

[14] NATO. Environmental File for a Compound. AJEPP-6. (STANAG XXXX, Ratification draft). Brussels: NATO Standardization Agency (NSA). 2011.

[15] EUFOR. Environmental Protection Policy. Brussels: European Defence Agency. 30 May 2005. 
[16] EUFOR. EP Policy: SOP 6292: Environmental Status Assessment Guidelines. Brussels: European Defence Agency. 5 September 2005.

[17] EUFOR/NATO. Policy - Environmental Management System. Brussels: European Defence Agency.31 March 2006.

[18] EUFOR/NATO. SOP 6293 - Structuring Of Environmental Staff. Brussels: European Defence Agency. 12 January 2007.

[19] NATO. Joint NATO Waste Management Requirements during NATO Led Military Activities. STANAG 2510. $2^{\text {nd }}$ Ed. Brussels: NATO Standardization Agency. 2009.

[20] Bozek, F., Urban, R. Risk Management - General Part. (Monograph.). $1^{\text {st }}$ Ed. Brno: University of Defence, 2008. 145 p. ISBN 978-80-7231259-7.

[21] Procházková, D., Bartlová, I. Check Lists for Assessing Safety of Technologies. In Safety and Health Protection at Work. Ostrava: Fire and Safety Engineering Association, 2006, s. 86-92. 80-86634-64-7.

[22] Dickert, T.G. Methods for Environmental Impact Assessment. $1^{\text {st }}$ Ed. Berkeley: University of California, 1974. 